\title{
Sensitivity of elongation factor Tu (EF-Tu) from different bacterial species to the antibiotics efrotomycin, pulvomycin and MDL 62879
}

\author{
Paolo Landini, Monica Bandera, Adolfo Soffientini and Beth P. Goldstein* \\ Marion Merrell Dow Research Institute, Lepetit Research Center, Via R. Lepetit 34, Gerenzano (Varese), Italy
}

(Received 1 September 1992; revised 13 November 1992; accepted 7 December 1992)

\begin{abstract}
The sensitivity of elongation factor Tu (EF-Tu) from different species of bacteria to the EF-Tu-binding antibiotics efrotomycin, pulvomycin and MDL 62879 was tested by measuring the effect of these antibiotics on cell-free protein synthesis systems. EF-Tu from four different Gram-negative species was sensitive to all three antibiotics. Among Gram-positive bacteria, EF-Tu of Bacillus subtilis, Staphylococcus aureus and Enterococcus faecalis was resistant to efrotomycin and less sensitive to pulvomycin than EF-Tu of Gram-negative bacteria. EF-Tus from streptococci were significantly less sensitive than EF-Tus from Gram-negative bacteria to both efrotomycin and pulvomycin. All of the EF-Tus were sensitive to MDL 62879. The same sensitivity pattern emerged from GDP exchange assays, performed with partially purified EF-Tu from different bacterial species and pure Escherichia coli EF-Ts. These results suggest that the site of action of MDL 62879 is more conserved among bacterial species than those of efrotomycin and pulvomycin. Heterogeneity of EF-Tus from different bacterial species was also reflected in differences in their apparent molecular masses estimated by SDS-PAGE. EF-Tus from the Gram-positive species had higher molecular masses than those from all but one of the Gram-negative species.
\end{abstract}

\section{Introduction}

Elongation factor $\mathrm{Tu}(\mathrm{EF}-\mathrm{Tu})$ is essential for bacterial protein synthesis and the gene encoding it (tuf) is highly conserved among eubacteria (Filer \& Furano, 1980). Three different types of antibiotic have been found to be inhibitors of EF-Tu: the kirromycin class, pulvomycin and MDL 62879 (formerly GE 2270 A). These antibiotics differ in chemical structure (Fig. 1), in the nature of their interaction with EF-Tu (Fasano et al., 1978; Wolf et al., 1974; Anborgh \& Parmeggiani, 1991) and in their spectrum of antibacterial activity (Selva et al., 1991). All three antibiotics are natural products: kirromycins and pulvomycin are produced by different species of Streptomyces, MDL 62879 by Planobispora rosea (Parmeggiani \& Swart, 1985; Akita et al., 1963; Selva et al., 1991).

Kirromycins stimulate the intrinsic GTPase activity of EF-Tu and block the protein in a non-dissociable ribosome-EF-Tu complex (Wolf et al., 1974; Fasano et al., 1978). MDL 62879 and pulvomycin inhibit the binding of aminoacyl-tRNA to EF-Tu. Pulvomycin increases the rates of association and dissociation of

*Author for correspondence. Tel. 2 96193329; fax 296193365.
GDP with EF-Tu; MDL 62879 does not affect these reactions (Anborgh \& Parmeggiani, 1991; Pingoud et al., 1982).

The antibacterial activities of the three antibiotics are quite different. MDL 62879 is active against Grampositive bacteria (Selva et al., 1991). Kirromycins are not active against some species of Gram-positive bacteria such as Bacillus subtilis, staphylococci and enterococci, but they are active against some Gram-negative bacteria such as Neisseria gonorrhoeae and Haemophilus influenzae (Frost et al., 1976, 1979) on which MDL 62879 has little or no activity. Pulvomycin is also active against $N$. gonorrhoeae and $H$. influenzae; among Gram-positive species it is active against staphylococci and enterococci, but has very poor activity against streptococci (Akita et al., 1963; Selva et al., 1991).

For kirromycins, it has been reported that an intrinsically resistant EF-Tu is responsible for resistance in B. subtilis (Smith \& Paress, 1978; Landini et al., 1992), Staphylococcus aureus (Hall et al., 1989) and some species of lactobacilli (Gloeckner \& Wolf, 1984; Woerner \& Wolf, 1982; Woerner et al., 1983). We have studied the sensitivity to MDL 62879, efrotomycin (a member of the kirromycin class) and pulvomycin of EF-Tu from several bacterial species by using cell-free protein synthesis assays and GDP exchange reactions. The aim of our 

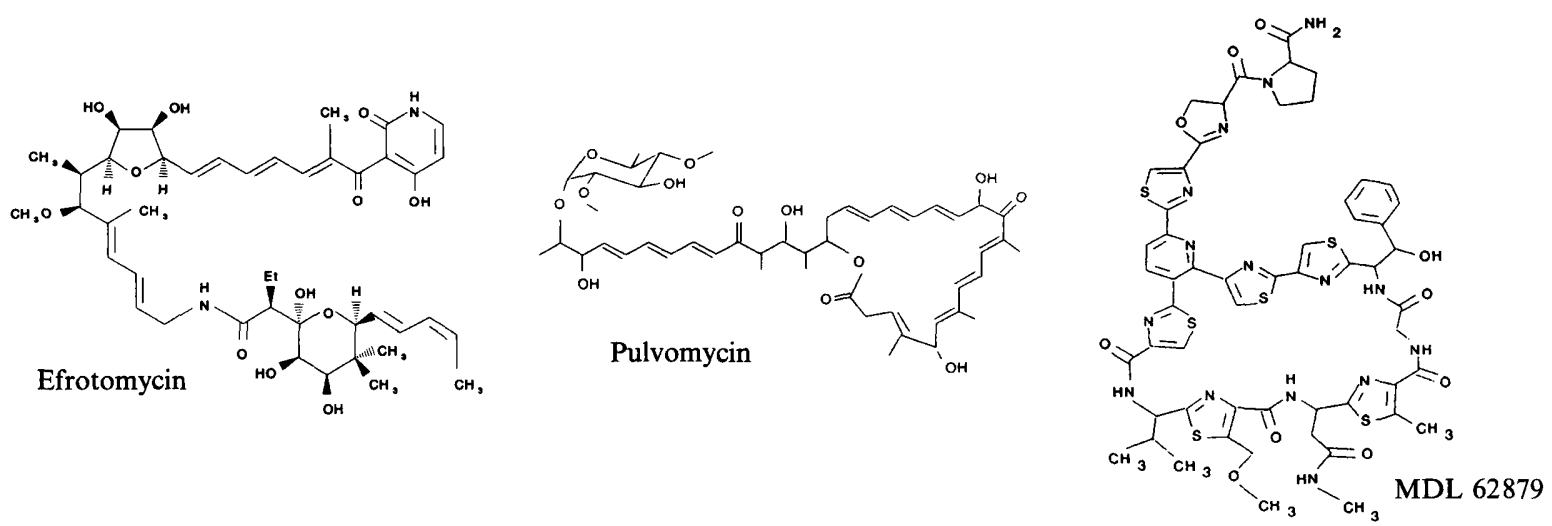

Fig. 1. Chemical structures of the antibiotics efrotomycin, pulvomycin and MDL 62879.

study was to further explore the extent to which the differences in the spectrum of antibacterial activity of the three antibiotics are mediated by EF-Tu or by other factors, such as penetration of the antibiotics into the bacteria, which is known to be the reason for resistance in Escherichia coli (Wolf et al., 1974, 1978; Selva et al., 1991).

\section{Methods}

Bacterial strains. The bacterial strains used for MIC determination and as sources of cell-free extracts are listed in Table 1.

Chemicals. MDL 62879 (1290 Da) and pulvomycin (838 Da) were prepared as described by Selva et al. (1991) at the Lepetit Research Center, Gerenzano, Italy. Efrotomycin (1145 Da) was from Merck Sharp and Dohme. For MIC determination the antibiotics were dissolved in dimethylformamide (DMF) at $10 \mathrm{mg} \mathrm{ml}^{-1}$ and diluted in water. For cell-free assays, MDL 62879 was dissolved at 50 -fold the final concentration in $50 \%(\mathrm{v} / \mathrm{v}) \mathrm{DMF}$; efrotomycin and pulvomycin were dissolved in $10 \% \mathrm{DMF}$ at 10 -fold the final concentration. DMF $(1 \%)$, always added to the controls, did not affect the assays. $\left[2,6-{ }^{3} \mathrm{H}\right] \mathrm{Phenylalanine}$ and $\left[8-{ }^{3} \mathrm{H}\right] \mathrm{GDP}$ were from Amersham. Electro-

\section{Table 1. Antibacterial activity of efrotomycin, pulvomycin and MDL 62879}

MIC determinations were performed in two independent experiments with the same results.

\begin{tabular}{|c|c|c|c|}
\hline \multirow[b]{2}{*}{ Species* } & \multicolumn{3}{|c|}{$\operatorname{MIC}\left(\mu \mathrm{g} \mathrm{ml}^{-1}\right)$} \\
\hline & Efrotomycin & Pulvomycin & MDL 62879 \\
\hline E. coli $\mathrm{K} 12 \mathrm{HfrC}$ & $>128$ & $>128$ & $>128$ \\
\hline N. gonorrhoeae L 997 & 0.25 & 0.13 & 32 \\
\hline H. influenzae ATCC 19418 & 4 & 16 & 128 \\
\hline P. aeruginosa ATCC 10145 & $>128$ & $>128$ & $>128$ \\
\hline B. subtilis ATCC 6633 & $>128$ & 2 & 0.13 \\
\hline Ent. faecalis ATCC 7080 & $>128$ & 16 & 0.25 \\
\hline Staph. aureus L 165 & $>128$ & 8 & 0.25 \\
\hline Strep. pyogenes L 49 & 16 & 128 & $0 \cdot 25$ \\
\hline Strep. gordonii Challis & 8 & 128 & $0 \cdot 13$ \\
\hline
\end{tabular}

* L, Lepetit Strain Collection; ATCC, American Type Culture Collection, Rockville, MD, USA. phoresis reagents and molecular mass standards were from Bio-Rad. All other chemicals were from Sigma.

MIC determination. MICs were determined as in Selva et al. (1991).

Preparation of cell-free protein synthesis systems. Bacteria (1 litre culture) were grown to early exponential phase $\left(\mathrm{OD}_{590} 0.2-0.6\right)$ and centrifuged at $13000 \mathrm{~g}$ for $10 \mathrm{~min}$ at $4{ }^{\circ} \mathrm{C}$. The cells were resuspended in $20 \mathrm{ml}$ of $0.85 \% \mathrm{NaCl}$ and recentrifuged.

The bacteria were disrupted as follows. B. subtilis, E. coli and $P$ seudomonas aeruginosa were broken by sonication. The cell paste was

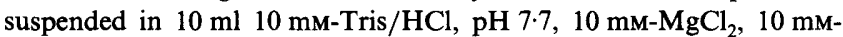
$\mathrm{NH}_{4} \mathrm{Cl}, 3 \mathrm{~mm}$-DTT, 0.25 mM-PMSF and leupeptin $\left(10 \mu \mathrm{g} \mathrm{ml}^{-1}\right)$, and sonicated on ice ( 10 cycles of $30 \mathrm{~s}$ with intervals of $30 \mathrm{~s}$ ). N. gonorrhoeae and $H$. influenzae cell pastes were resuspended in $10 \mathrm{ml}$ protoplasting buffer ( 50 mM-Tris/HCl, pH 7.9, 5 mm-EDTA, 3 mm-DTT, $25 \%$, w/v, sucrose, $0.25 \mathrm{mM}$-PMSF, $10 \mu \mathrm{g}$ leupeptin $\mathrm{ml}^{-1}$ ) and then incubated with lysozyme $\left(100 \mu \mathrm{g} \mathrm{ml}^{-1}\right)$, lysostaphin $\left(100 \mu \mathrm{g} \mathrm{ml}^{-1}\right)$ and mutanolysin $\left(20 \mu \mathrm{g} \mathrm{ml}^{-1}\right)$ for $30 \mathrm{~min}$ at $37^{\circ} \mathrm{C}$ followed by overnight incubation on ice. The protoplasts were pelleted by centrifugation at $30000 \mathrm{~g}$ for $30 \mathrm{~min}$ at $4{ }^{\circ} \mathrm{C}$. The supernatant was collected, and the protoplasts were resuspended in $10 \mathrm{ml}$ protoplasting buffer without sucrose and homogenized with a Dounce homogenizer (12 strokes on ice). The homogenate was incubated at $37^{\circ} \mathrm{C}$ for $30 \mathrm{~min}$ and centrifuged at $30000 \mathrm{~g}$ for $30 \mathrm{~min}$ at $4{ }^{\circ} \mathrm{C}$. The two supernatants were pooled and dialysed overnight against $10 \mathrm{mM}-\mathrm{Tris} / \mathrm{HCl}, \mathrm{pH} 7 \cdot 5,10 \mathrm{mM}-$ $\mathrm{MgCl}_{2}, 0.25$ mM-PMSF.

Staph. aureus and Enterococcus faecalis were lysed using the enzymic method described by Georgopapadakou et al. (1982). Streptococcus pyogenes and Strep. gordonii were lysed as described by Siegel et al. (1981), except that lysozyme $\left(200 \mu \mathrm{g} \mathrm{ml}^{-1}\right)$ and lysostaphin $\left(20 \mu \mathrm{g} \mathrm{ml}^{-1}\right)$ were added as well as mutanolysin $\left(20 \mu \mathrm{g} \mathrm{ml}^{-1}\right)$.

All cell lysates were centrifuged at $30000 \mathrm{~g}$ for $30 \mathrm{~min}$ and the supernatant (S-30) was collected. The various S-30 obtained were centrifuged at $100000 \mathrm{~g}$ for $4 \mathrm{~h}$ at $2{ }^{\circ} \mathrm{C}$. The ribosomal pellets were discarded, except for ribosomes from $E$. coli, which were resuspended in one-tenth of the S-30 volume in $10 \mathrm{~mm}-\mathrm{Tris} / \mathrm{HCl}, \mathrm{pH} 7 \cdot 7,10 \mathrm{~mm}$ $\mathrm{MgCl}_{2}$ and washed with $0.6 \mathrm{M}-\mathrm{NH}_{4} \mathrm{Cl}$ to remove adherent protein factors as described by Traub et al. (1971). The supernatants (S-100) were concentrated by ammonium sulphate fractionation at $30-65 \%$ of saturation (Ravel \& Shorey, 1971). The $65 \%$ ammonium sulphate precipitate was resuspended in one-fifth of the S- 100 volume in $10 \mathrm{mM}$ Tris/HCl, pH 7.7, $10 \mathrm{~mm}-\mathrm{MgCl}_{2}, 0.25 \mathrm{~mm}-\mathrm{PMSF}$. This fraction (termed $\mathrm{S}-100^{\prime}$ ) was used as the source of protein synthesis factors and for purification of EF-Tu.

Poly(U)-directed poly(Phe) synthesis. Poly(U)-directed poly(Phe) synthesis was performed as described by Traub et al. (1971), using a 
mixed system in which $\mathrm{NH}_{4} \mathrm{Cl}$-washed ribosomes $(5 \mathrm{pmol})$ were from $E$. coli and S-100' from different bacteria. The S-100' added for the cellfree assays contained 3-8 $\mu \mathrm{g}$ protein $\mathrm{ml}^{-1}$. Assays were performed in $100 \mu l 30$ mm-Tris/HCl, pH 7.7, 10 mu- $\mathrm{MgCl}_{2}, 80 \mathrm{~mm}-\mathrm{NH}_{4} \mathrm{Cl}, 3 \mathrm{~mm}-$ DTT, $5 \mathrm{~mm}-\mathrm{GTP}, 4 \mathrm{~mm}-\mathrm{ATP}$ with $80 \mu \mathrm{g}$ poly(U) and $50 \mathrm{pmol}$ $\left[{ }^{3} \mathrm{H}\right]$ phenylalanine [specific activity $\left.12 \mathrm{Ci} \mathrm{mmol}^{-1}(1 \mathrm{Ci}=37 \mathrm{GBq})\right]$. Incubation was for $15 \mathrm{~min}$ at $30^{\circ} \mathrm{C}$. Protein synthesis was stopped by adding trichloroacetic acid to a final concentration of $5 \%(\mathrm{w} / \mathrm{v})$. The samples were heated for $10 \mathrm{~min}$ at $80^{\circ} \mathrm{C}$, cooled on ice and filtered on glass fibre filters using a cell-harvester (LKB).

Partial purification of EF-Tu. EF-Tu from the various species was partially purified by GDP-sepharose chromatography of the S-100' fraction. The S-100' fraction was made up to $0.35 \mathrm{M}-\mathrm{NaCl}$ and loaded on the column resin $\left[2 \mathrm{mg}\right.$ protein $\left.(\mathrm{ml} \text { resin })^{-1}\right]$ which had been equilibrated with buffer A (20 mM-Tris/ $\mathrm{HCl}, \mathrm{pH} \mathrm{7.9,} 10 \mathrm{~mm}-\mathrm{MgCl}_{2}$, $5 \mathrm{~mm}$-DTT, $0.25 \mathrm{~mm}$-PMSF, $0.35 \mathrm{M}-\mathrm{NaCl}$ ). The column was washed with 5 vols buffer A and EF-Tu was eluted with buffer A containing $2 \mathrm{mM}$-GDP. The degree of purification was monitored by SDS-PAGE ( $20 \%$ acrylamide, $0.48 \%$ bisacrylamide) in a Phastgel Electrophoresis system (Pharmacia).

Purified EF-Tus from various species were tested for their ability to stimulate poly(Phe) synthesis in the presence of $\mathrm{NH}_{4} \mathrm{Cl}$-washed ribosomes and purified EF-Ts and EF-G from E. coli. The assay mixture contained 5 pmol ribosomes, 10 pmol EF-Ts, 10 pmol EF-G, 12 pmol $\left[{ }^{3} \mathrm{H}\right]$ phenylalanyl-tRNA, charged and isolated as described by Ravel \& Shorey (1971), and partially purified EF-Tu (0.25 $\mu$ g, approx. $5 \mathrm{pmol}$ ) from various species. Otherwise, the assay conditions were the same as for poly(U) assays performed with S-100. EF-Ts and EF-G were purified as described by Leberman et al. (1980).

GDP exchange assays. GDP exchange assays were performed as described by Fasano et al. (1978) using approximately 10 pmol EFTu-GDP (unlabelled) from various bacterial species, 2 pmol EF-Ts from $E$. coli, and 100 pmol $\left[{ }^{3} \mathrm{H}\right] \mathrm{GDP}$ (specific activity $10 \mathrm{Ci} \mathrm{mmol}^{-1}$ ). Incubation was for $5 \mathrm{~min}$ at $0^{\circ} \mathrm{C}$ in a final volume of $100 \mu \mathrm{l}$ of reaction buffer ( $80 \mathrm{~mm}-\mathrm{NH}_{4} \mathrm{Cl}, 50 \mathrm{~mm}-\mathrm{Tris} / \mathrm{HCl}, \mathrm{pH} 7.8,10 \mathrm{~mm}-\mathrm{MgCl}_{2}, 3 \mathrm{~mm}-$ DTT). Reactions were stopped by the addition of $1 \mathrm{ml}$ cold reaction buffer. Samples were immediately filtered on nitrocellulose filters (HAWP0045, Millipore) and the filters were washed with $6 \mathrm{ml}$ of buffer.

Determination of radioactivity. Glass fibre filters were counted in a $\beta$-plate scintillation counter (Pharmacia). Nitrocellulose filters were dried and then counted by liquid scintillation.

\section{Results}

\section{Antibacterial activity}

MIC values of the three antibiotics, determined on aliquots of the cultures used to prepare $\mathrm{S}-100^{\prime}$, are shown in Table 1. The results are in good agreement with data from the literature (Frost et al., 1979; Selva et al., 1991).

\section{Cell-free protein synthesis}

Table 2 shows the $\mathrm{IC}_{50}$ (the extrapolated antibiotic concentration at which the reaction is inhibited by $50 \%$ ) of efrotomycin, pulvomycin and MDL 62879 against S-100' from Gram-negative bacteria. All of these cellfree protein synthesis systems were very sensitive to the three antibiotics, with little difference in the $\mathrm{IC}_{50}$ values.
The $\mathrm{IC}_{50}$ values of efrotomycin, pulvomycin and MDL 62879 in cell-free extracts of Gram-positive bacteria are shown in Table 3. Cell-free protein synthesis in extracts from kirromycin-resistant bacteria was unaffected by efrotomycin $\left(\mathrm{IC}_{50}>100 \mu \mathrm{g} \mathrm{ml}^{-1}\right.$ for $B$. subtilis and Staph. aureus, and $50 \mu \mathrm{g} \mathrm{ml}^{-1}$ for Ent. faecalis), suggesting that in these species resistance to efrotomycin is mediated by EF-Tu. Pulvomycin was less active in cellfree extracts from Staph. aureus and Ent. faecalis $\left(\mathrm{IC}_{50}\right.$ 0.7 and $1.1 \mu \mathrm{g} \mathrm{ml}^{-1}$, respectively) than in $B$. subtilis $\left(\mathrm{IC}_{50}\right.$ $0.21 \mu \mathrm{g} \mathrm{ml}^{-1}$ ) or in Gram-negative bacteria (Table 2). MDL 62879 was active at concentrations of $0 \cdot 02-0 \cdot 12 \mu \mathrm{g}$ $\mathrm{ml}^{-1}$ in cell-free systems from Staph. aureus, Ent. faecalis and $B$. subtilis.

The streptococcal cell-free protein synthesis systems responded differently as compared both to the Gramnegative and to the other Gram-positive bacteria. Both efrotomycin $\left(\mathrm{IC}_{50} 0.65\right.$ for Strep. pyogenes and $1 \mu \mathrm{g} \mathrm{ml}^{-1}$

Table 2. Activity of efrotomycin, pulvomycin and $M D L$ 62879 in cell-free poly (Phe) synthesis using $S-100^{\prime}$ from Gram-negative bacteria

$\mathrm{IC}_{50}$ values are the means of two independent experiments which gave very similar results. Ribosomes $(5 \mathrm{pmol})$ were from $E$. coli. S- $100^{\prime}$ added contained $3-8 \mu \mathrm{g}$ protein. The assay mixture also contained: $80 \mu \mathrm{g}$ poly $(\mathrm{U}), 50 \mathrm{pmol}\left[{ }^{3} \mathrm{H}\right]$ phenylalanine $(12 \mathrm{Ci}$ $\left.\mathrm{mmol}^{-1}\right), 0.6 \mu \mathrm{g}$ E. coli tRNA ${ }^{\text {Phe }}, 30 \mathrm{~mm}-\mathrm{Tris} / \mathrm{HCl}, \mathrm{pH} 7 \cdot 7,10 \mathrm{~mm}-$ $\mathrm{MgCl}_{2}, 80 \mathrm{mM}-\mathrm{NH}_{4} \mathrm{Cl}, 3 \mathrm{~mm}$-DTT, $5 \mathrm{~mm}-\mathrm{GTP}$ and $4 \mathrm{mM}-\mathrm{ATP}$.

\begin{tabular}{|c|c|c|c|c|}
\hline \multirow[b]{2}{*}{ Source of S-100 } & \multirow{2}{*}{$\begin{array}{l}\text { Control } \\
(\mathrm{pmol})^{*}\end{array}$} & \multicolumn{3}{|c|}{$\mathrm{IC}_{50}\left(\mu \mathrm{g} \mathrm{ml}^{-1}\right)$} \\
\hline & & Efrotomycin & Pulvomycin & MDL 62879 \\
\hline E. coli & $9 \cdot 48$ & 0.02 & 0.06 & 0.04 \\
\hline$P$. aeruginosa & $9 \cdot 93$ & 0.04 & 0.06 & 0.04 \\
\hline H. influenzae & $8 \cdot 74$ & 0.07 & 0.3 & 0.05 \\
\hline N. gonorrhoeae & $2 \cdot 88$ & 0.08 & 0.02 & 0.02 \\
\hline
\end{tabular}

${ }^{*}\left[{ }^{3} \mathrm{H}\right] \mathrm{Phenylalanine}$ incorporated in $15 \mathrm{~min}$ at $30^{\circ} \mathrm{C}$. E. coli ribosomes without the addition of S- $100^{\prime}$ incorporated 0.03 pmol.

Table 3. Activity of efrotomycin, pulvomycin and $M D L$ 62879 in cell-free poly(Phe) synthesis using $S-100^{\prime}$ from Gram-positive bacteria

$\mathrm{IC}_{50}$ values are the means of two independent experiments which gave very similar results. Conditions as described in the legend to Table 2 .

\begin{tabular}{lcccc}
\hline \hline & & \multicolumn{3}{c}{$\mathrm{IC}_{50}\left(\mu \mathrm{g} \mathrm{ml}^{-1}\right)$} \\
\cline { 3 - 5 } Source of S-100 & $\begin{array}{l}\text { Control } \\
(\mathrm{pmol})^{*}\end{array}$ & Efrotomycin & Pulvomycin & MDL 62879 \\
\hline B. subtilis & 6.36 & $>100$ & 0.21 & 0.12 \\
Staph. aureus & 3.40 & $>100$ & 0.7 & 0.02 \\
Ent. faecalis & 0.67 & 50 & $1 \cdot 1$ & 0.02 \\
Strep. pyogenes & 4.55 & 0.65 & 2.45 & 0.18 \\
Strep. gordonii & 7.96 & 1.0 & 2.05 & 0.11 \\
\hline \hline
\end{tabular}

${ }^{*}\left[{ }^{3} \mathrm{H}\right] \mathrm{Phenylalanine}$ incorporated in $15 \mathrm{~min}$ at $30^{\circ} \mathrm{C}$. E. coli ribosomes without the addition of S- $100^{\prime}$ incorporated $0.03 \mathrm{pmol}$. 


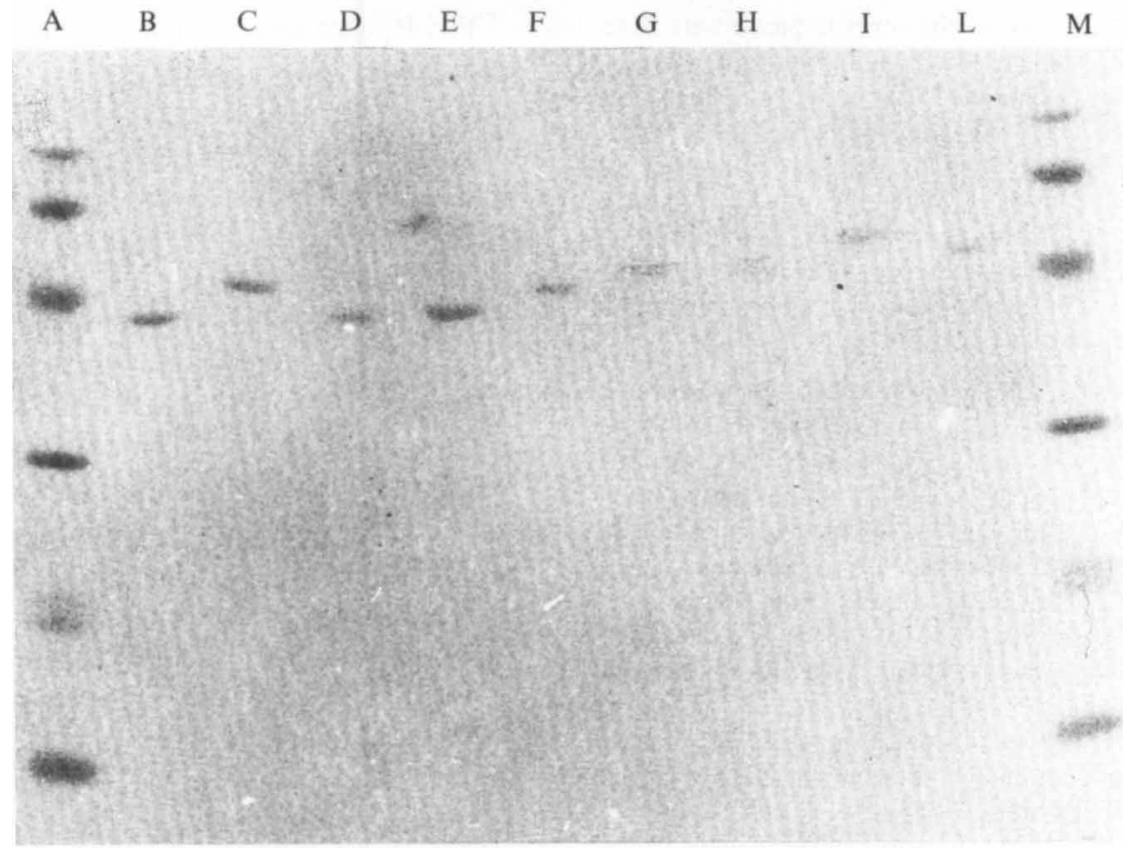

Fig. 2. SDS-PAGE of partially purified EF-Tus from different bacterial species. Lanes A and M, molecular mass standards (phosphorylase $b, 97.4 \mathrm{kDa}$; bovine serum albumin, 66; ovalbumin, 45; carbonic anhydrase, 30; soybean trypsin inhibitor, 21.4; lactalbumin, 14.2). Lanes B-L: EF-Tu (estimated molecular masses in parentheses) from B, $N$. gonorrhoeae ( $42.5 \mathrm{kDa}) ; \mathrm{C}, H$. influenzae (47); D, P. aeruginosa (42.5); E, E. coli (42.5); F, B. subtilis (45); G, Strep. pyogenes (48); H, Strep. gordonii (48); I, Ent. faecalis (52); L, Staph. aureus $(50 \cdot 5)$.

Table 4. Effect of efrotomycin, pulvomycin or MDL 62879 (each at $20 \mu \mathrm{g}$ $\mathrm{ml}^{-1}$ ) on $E F-T u-G D P /\left[{ }^{3} \mathrm{H}\right] G D P$ exchange mediated by $E F-T u$ from various bacterial species and EF-Ts from $E$. coli

Results are expressed as pmol $\left[{ }^{3} \mathrm{H}\right] \mathrm{GDP}$ bound to EF-Tu in 5 min at $0{ }^{\circ} \mathrm{C}$ (means from two experiments, each with duplicate determinations; SD in parentheses). The experimental values are also shown as percentages of the control, calculated from the mean values of the four determinations.

\begin{tabular}{|c|c|c|c|c|c|c|c|}
\hline \multirow[b]{2}{*}{ Species } & \multirow{2}{*}{$\begin{array}{c}\text { Control } \\
\text { (pmol) }\end{array}$} & \multicolumn{2}{|c|}{ Efrotomycin } & \multicolumn{2}{|c|}{ Pulvomycin } & \multicolumn{2}{|c|}{ MDL 62879} \\
\hline & & (pmol) & $(\%)$ & $(\mathrm{pmol})$ & $(\%)$ & $(\mathrm{pmol})$ & $(\%)$ \\
\hline Staph. aureus & $0.64(0.02)$ & $0.62(0.02)$ & 97 & $0.51(0.04)$ & 80 & $0.63(0.01)$ & 98 \\
\hline Ent. faecalis & $0.30(0.01)$ & $0.29(0.01)$ & 97 & $0.25(0.01)$ & 83 & $0.31(0.01)$ & 103 \\
\hline Strep. pyogenes & $0.80(0.04)$ & $0.61(0.02)$ & 76 & $0.73(0.06)$ & 91 & $0.81(0.04)$ & 101 \\
\hline Strep. gordonii & $0.76(0.10)$ & $0.54(0.03)$ & 71 & $0.62(0.02)$ & 82 & $0.73(0.02)$ & 96 \\
\hline B. subtilis & $1.69(0 \cdot 14)$ & $1.79(0.06)$ & 106 & $1.47(0.02)$ & 87 & $1.75(0.16)$ & 104 \\
\hline E. coli & $2.26(0.05)$ & $0.87(0.07)$ & 39 & $1.07(0 \cdot 10)$ & 47 & $2.23(0.04)$ & 99 \\
\hline P. aeruginosa & $0.96(0.07)$ & $0.42(0.02)$ & 44 & $0.46(0.04)$ & 48 & $0.94(0 \cdot 11)$ & 98 \\
\hline N. gonorrhoeae & $2.96(0.09)$ & $1.03(0.07)$ & 35 & $1.41(0.08)$ & 48 & $2.78(0.04)$ & 94 \\
\hline H. influenzae & $3.20(0 \cdot 16)$ & $1 \cdot 19(0.01)$ & 37 & $1.57(0.18)$ & 49 & $3 \cdot 08(0 \cdot 25)$ & 96 \\
\hline
\end{tabular}

for Strep. gordonii) and pulvomycin ( $\mathrm{IC}_{50} 2 \cdot 45$ and $2.0 \mu \mathrm{g}$ $\mathrm{ml}^{-1}$ ) were less active here than in Gram-negative systems. In contrast, the $\mathrm{IC}_{50}$ of MDL 62879 were similar to those obtained for other bacteria $(0.18$ and $0.11 \mu \mathrm{g}$ $\mathrm{ml}^{-1}$ for Strep. pyogenes and Strep. gordonii, respectively).

\section{Purification of EF-Tu}

The EF-Tus of all of the species considered were partially purified by affinity chromatography on GDP-Sepharose. SDS-PAGE of the partially purified EF-Tus, with their apparent molecular masses, is shown in Fig. 2. Gram- 
positive bacteria appear to have EF-Tus with higher molecular masses than those of most of Gram-negative bacteria. E. coli, $P$. aeruginosa and $N$. gonorrhoeae had an EF-Tu with the same molecular mass $(42.5 \mathrm{kDa})$; $H$. influenzae was the only Gram-negative species whose $\mathrm{EF}-\mathrm{Tu}(47 \mathrm{kDa})$ appeared to be larger than those of some of the Gram-positive species.

These EF-Tu preparations stimulated cell-free poly(Phe) synthesis in the presence of washed ribosomes, EF-Ts and EF-G from E. coli, suggesting that the bands seen on SDS-PAGE do represent the EF-Tu of the various species. The system without EF-Tu incorporated $0.06 \mathrm{pmol}$ phenylalanine. The degree of stimulation obtained with approximately 5 pmol EF-Tu from different species ranged from sevenfold with EF-Tu from Ent. faecalis to about 100-fold for EF-Tu from Gramnegative bacteria (data not shown).

\section{GDP-exchange assays}

The effect of efrotomycin, pulvomycin and MDL 62879 on EF-Tu-GDP $/\left[{ }^{3} \mathrm{H}\right] \mathrm{GDP}$ exchange (GDP-exchange) in the presence of EF-Ts from $E$. coli was tested using partially purified EF-Tu from the various species (Table 4). MDL 62879, at a concentration of $20 \mu \mathrm{g} \mathrm{ml}^{-1}$, had no effect on the GDP-exchange reaction mediated by any of the EF-Tus. With EF-Tu from Gram-negative bacteria, efrotomycin inhibited GDP-exchange by about $60 \%$. With streptococcal EF-Tu, the reaction was only slightly inhibited by efrotomycin (by $24 \%$ for Strep. pyogenes and $29 \%$ for Strep. gordonii), and there was no inhibition when EF-Tus from B. subtilis, Staph. aureus or Ent. faecalis were used. With EF-Tu from Gram-negative bacteria, pulvomycin inhibited GDP-exchange by about $50 \%$, whereas it only slightly inhibited the reaction with EF-Tu of Gram-positive species (10-20\%).

\section{Discussion}

EF-Tu from $E$. coli had already been reported to be sensitive to efrotomycin, pulvomycin and MDL 62879 , indicating that these antibiotics do not penetrate into $E$. coli cells (Wolf et al., 1974, 1978; Selva et al., 1991). Our results suggest that the mechanism of resistance is the same for all three antibiotics in the case of $P$. aeruginosa, and for MDL 62879 in N. gonorrhoeae and $H$. influenzae. Our data also indicate that the binding sites of the three inhibitors are highly conserved among Gram-negative species.

The situation is more complex in Gram-positive bacteria. MDL 62879 is the only EF-Tu inhibitor which was active against all of the Gram-positive species tested, inhibiting both cell growth and cell-free protein synthesis
(Tables 1 and 3). Thus the binding site of MDL 62879 appears to be highly conserved in EF-Tu from Grampositive bacteria as well as in Gram-negative species.

Efrotomycin did not inhibit cell-free protein synthesis in cell extracts from B. subtilis, Staph. aureus or Ent. faecalis, which are resistant to this antibiotic. For $B$. subtilis and Staph. aureus (as well as for some species of lactobacilli) similar observations have been reported for the kirromycins (Smith \& Paress, 1978; Woerner \& Wolf, 1982; Hall et al., 1989). Therefore, naturally occurring resistance to kirromycins in Gram-positive bacteria seems to be mediated by a resistant EF-Tu. Cellfree systems from streptococci were also somewhat less sensitive to efrotomycin than those from Gram-negative bacteria. Thus, the kirromycin binding site on EF-Tu of Gram-positive bacteria appears to be less conserved than that of Gram-negative species.

Among the Gram-positive bacteria considered, $B$. subtilis was the most sensitive to pulvomycin in terms of MIC $\left(2 \mu \mathrm{g} \mathrm{ml}^{-1}\right)$ and in sensitivity of cell-free protein synthesis $\left(\mathrm{IC}_{50} 0 \cdot 21 \mu \mathrm{g} \mathrm{ml}^{-1}\right)$. Staph. aureus and Ent. faecalis were less sensitive to pulvomycin (MIC 8 and $16 \mu \mathrm{g} \mathrm{ml}^{-1}$, respectively) and also showed a reduced sensitivity in cell-free assays $\left(\mathrm{IC}_{50} 0.7\right.$ and $1.1 \mu \mathrm{g} \mathrm{ml}^{-1}$, respectively). In streptococcal cell-free assays the activity of pulvomycin $\left(\mathrm{IC}_{50} 2.0\right.$ and $2.45 \mu \mathrm{g} \mathrm{ml}^{-1}$ ) indicates a lower sensitivity of their EF-Tu. However, the MIC of pulvomycin for these bacteria is particularly high $(128 \mu \mathrm{g}$ $\mathrm{ml}^{-1}$ ) and may not be totally explained by reduced interaction of pulvomycin with EF-Tu. In any event, our data suggest that the pulvomycin-binding site is not highly conserved among Gram-positive bacteria.

The effects of efrotomycin, pulvomycin and MDL 62879 on the GDP-exchange reaction have been described for EF-Tu and for EF-Tu:EF-Ts (EF-T) from E. coli. Efrotomycin and pulvomycin stimulate GDP exchange on EF-Tu (Van der Meide et al., 1980; Wolf et al., 1974, 1978). EF-Ts enhances the rate of GDPexchange, but this effect disappears in the presence of efrotomycin or pulvomycin, possibly because these antibiotics compete with EF-Ts in binding to EF-Tu (Fasano et al., 1978; Parmeggiani \& Swart, 1985).

We performed GDP-exchange assays in the presence of pure EF-Ts from E. coli. MDL 62879 does not affect this reaction either with E. coli EF-Tu alone (Anborgh \& Parmeggiani, 1991) or with EF-Tu from different bacterial species in the presence of EF-Ts (Table 4). The effects of efrotomycin and pulvomycin on the GDPexchange reaction with EF-Tu from different species and E. coli EF-Ts paralleled in most cases the sensitivity patterns of the various EF-Tus in the poly(Phe) synthesis assays. Thus, efrotomycin did not inhibit exchange with EF-Tu from the efrotomycin-resistant bacteria, and only slightly inhibited EF-Tu from Strep. pyogenes or Strep. 
gordonii. Pulvomycin inhibited GDP-exchange with EFTu from Gram-negative species, but only slightly in Gram-positive species; even EF-Tu from B. subtilis, which was the most sensitive to pulvomycin among Gram-positive bacteria in the protein synthesis assay, was only slightly inhibited in GDP-exchange experiments.

It has already been reported that there is some degree of heterogeneity in the molecular masses of EF-Tu from different bacterial species as estimated by SDS-PAGE (Woerner et al., 1983). The EF-Tus of the Gram-positive bacteria we studied had apparent molecular masses ranging from 45 to $52 \mathrm{kDa}$, whereas those from the Gram-negative bacteria ranged from 42.5 to $47 \mathrm{kDa}$ (Fig. 1). Previous SDS-PAGE estimates of the molecular mass of EF-Tu from B. subtilis and E. coli were 47 and $44 \mathrm{kDa}$, respectively (Woerner et al., 1983), values similar to those estimated by us ( 45 and $42.5 \mathrm{kDa})$. In the case of $E$. coli EF-Tu, the SDS-PAGE estimates are close to the molecular mass calculated from the amino acid sequence (43225 Da; Arai et al., 1980). Hall et al. (1991) reported a molecular mass of $41 \mathrm{kDa}$ for the EF-Tu of Staph. aureus, which is much lower than our estimate of $50.5 \mathrm{kDa}$. It is possible that Hall et al. (1991) encountered degradation problems during their purification of Staph. aureus $\mathrm{EF}-\mathrm{Tu}$.

\section{References}

Akita E., Maeda, K. \& Umezawa, H. (1963). Isolation and characterization of labilomycin, a new antibiotic. Journal of Antibiotics 16, 147-151.

Anborgh, P. H. \& Parmeggiani, A. (1991). New antibiotic that acts specifically on the GTP-bound form of elongation factor Tu. EMBO Journal 10, 779-784.

Arai, K., Clark, B. F. C., Duffy, L., Jones, M. D., Kaziro, Y., Laursen, R. A., L'Italien, J., Miller, D. L., Nagarkatti, S., Nakamura, S., Nielsen, K. M., Petersen, T. E., Takahashi, K. \& WADE, M. (1980). Primary structure of elongation factor Tu from Escherichia coli. Proceedings of the National Academy of Sciences of the United States of America 77, 1326-1330.

Fasano, O., Bruns, W., Crechet, J.-B., Sander, G. \& Parmeggiani, A. (1978). Modification of elongation-factor-Tu $\cdot$ guanine-nucleotide interaction by kirromycin. European Journal of Biochemistry 89, 557-565.

Filer, D. \& Furano, A. V. (1980). Portions of the gene encoding elongation factor Tu are highly conserved in prokaryotes. Journal of Biological Chemistry 255, 728-734.

Frost, B. M., Valiant, M. E., Weissberger, B. \& Dulaney, E. L. (1976). Antibacterial activity of efrotomycin. Journal of Antibiotics 29, 1083-1091.

Frost, B. M., Valiant, M. E. \& Dulaney, E. L. (1979). Antibacterial activity of heneicomycin. Journal of Antibiotics 32, 626-629.

Georgopapadakou, N. H., Smith, S. A. \& Bonner, D. P. (1982). Penicillin binding proteins in a Staphylococcus aureus strain resistant to specific $\beta$-lactam antibiotics. Antimicrobial Agents and Chemotherapy 22, 172-175.
GloeCKNER, C. \& Wolf, H. (1984). Mechanism of natural resistance to kirromycin-type antibiotics in actinomycetes. FEMS Microbiology Letters 25, 121-124.

Hall, C. C., Watkins, J. D. \& Georgopapadakou, N. H. (1989). Effects of elfamycins on elongation factor Tu from Escherichia coli and Staphylococcus aureus. Antimicrobial Agents and Chemotherapy 33, 322-325.

Hall, C. C., Watkins, J. D. \& Georgopapadakou, N. H. (1991). Comparison of the $\mathrm{Tu}$ elongation factors from Staphylococcus aureus and Escherichia coli: possible basis for elfamycin insensitivity. Antimicrobial Agents and Chemotherapy 35, 2366-2370.

Landini, P., Bandera, M., Goldstein, B. P., Ripamonti, F., SoffientinI, A., IsLam, K. \& Denaro, M. (1992). Inhibition of bacterial protein synthesis by elongation factor Tu-binding antibiotics MDL 62879 and efrotomycin. Biochemical Journal 283, 649-652.

Leberman, R., Antonsson, B., Giovanelli, R., Guariguata, R., SCHUMANN, R. \& WitTinghofeR, A. (1980). A simplified procedure for the isolation of bacterial polypeptide elongation factor EF-Tu. Analytical Biochemistry 104, 29-36.

Parmeggiani, A. \& Swart, G. W. M. (1985). Mechanism of action of kirromycin-like antibiotics. Annual Reviews of Microbiology 39, 557-577.

Pingoud, A., Block, W., Urbanke, C. \& Wolf, H. (1982). The antibiotics kirromycin and pulvomycin bind to different sites on the elongation factor Tu from Escherichia coli. European Journal of Biochemistry 123, 261-265.

RAVEL, J. M. \& SHOREY, R. L. (1971). GTP-dependent binding of aminoacyl-tRNA to Escherichia coli ribosomes. Methods in Enzymology 20, 306-316.

Selva, E., Beretta, G., Montanini, M., Saddler, G. S., Gastaldo, L., Ferrari, P., Lorenzetti, R., Landini, P., Ripamonti, F., Goldstein, B. P., Berti, M., Montanaro, L. \& Denaro, M. (1991). Antibiotic GE $2270 \mathrm{~A}$ : a novel inhibitor of bacterial protein synthesis. Journal of Antibiotics 44, 693-701.

Siegel, J. L., Hurst, S. F., Liberman, E. S., Coleman, S. E. \& BLEIWEIS, A. S. (1981). Mutanolysin-induced spheroplasts of Streptococcus mutans are true protoplasts. Infection and Immunity 31, 808-815.

SMITH, I. \& PARESS, P. (1978). Genetic and biochemical characterization of kirromycin resistance mutations in Bacillus subtilis. Journal of Bacteriology 135, 1107-1117.

Traub, P., Mizushima, S., Lowry, C. V. \& Nomura, M. (1971). Reconstitution of ribosomes from subribosomal components. Methods in Enzymology 20, 306-316.

Van der Meide, P. H., Borman, T. H., Van Kimmenade, A. M. A., VAN DE PUTTE, P. \& BosCh, L. (1980). Elongation factor Tu isolated from Escherichia coli mutants altered in tufA and tuf $\mathrm{B}$. Proceedings of the National Academy of Sciences of the United States of America 77, 3922-3926.

WOERNER, W. \& WOLF, H. (1982). Kirromycin-resistant elongation factor Tu from wild-type of Lactobacillus brevis. FEBS Letters 146, $322-326$.

Woerner, W., Gloeckner, C., Mierzowski, M. \& Wolf, H. (1983). On heterogeneity of elongation factor Tu among eubacteria. FEMS Microbiology Letters 18, 69-73.

Wolf, H., Chinali, G. \& Parmeggian, A. (1974). Kirromycin, an inhibitor of protein biosynthesis that acts on elongation factor $\mathrm{Tu}$. Proceedings of the National Academy of Sciences of the United States of America 71, 4910-4914.

Wolf, H., Chinali, G. \& Parmeggiani, A. (1977). Mechanism of inhibition of protein synthesis by kirromycin. European Journal of Biochemistry 75, 67-75.

Wolf, H., AssmanN, D. \& Fischer, E. (1978). Pulvomycin, an inhibitor of protein biosynthesis preventing ternary complex formation between elongation factor Tu, GTP and aminoacyl tRNA. Proceedings of the National Academy of Sciences of the United States of America 75, 5324-5328. 